\title{
Chapter 14 \\ Staging the Pirate: The Ambiguities of Representation and the Significance of \\ Convention
}

\author{
Victor Emeljanow
}

The tradition of nineteenth-century pirate representation demonstrates a complex intertwining of the strands of popular literature and theatre. Popular theatrical performances included the latest technological developments, and their scripts appropriated fictional narratives and scenes from contemporary painting. Equally, novelists and painters used the theatrical staging of situation and character as modes of representation. As Martin Meisel points out, 'the shared structures in the representational arts constitute not just a common style but a popular style' (4). At the same time, Meisel argues, nineteenth-century arts and entertainment aspired 'to a union of inward signification, moral and teleological as well as affective, with a weighty, vivid, detailed and documented rendering of reality' (13). It is within this context that the pirate becomes a key figure in the complex discourse of performance conventions, which themselves embody outward signification and the desire for verisimilitude.

Any discussion of the representation, or staging, of the pirate must therefore acknowledge the contributions of the actors who impersonated him and the dramatic genres of melodrama, burlesque and pantomime, which enabled audiences to position the pirate within the world of archetypal villainy and heroism, or in that of mocking ironization. Equally important in the development of this representation is the appropriation of melodramatic narratives by the emerging industry of juvenile literature from 1851 onwards and the representation of these narratives in the miniaturized toy theatres of the so-called Juvenile Drama from 1811 onwards. In this chapter I shall consider the development of the stage pirate in the nineteenth century by examining popular dramas like Peter Pan and The Red Rover alongside less well-known works (including private, domestic performances like those of the juvenile theatre) to reflect upon the dramatic forces that combined to shape the image of the stage pirate that we know and love today.

As Pirates of the Caribbean draws its inspiration from the flamboyant impersonations of Tyrone Power and Errol Flynn, so in turn their films drew inspiration from the novels of Rafael Sabatini and the representations of pirates by Howard Pyle for magazines like Scribner's and Harper's Monthly (Figure 14.1). 


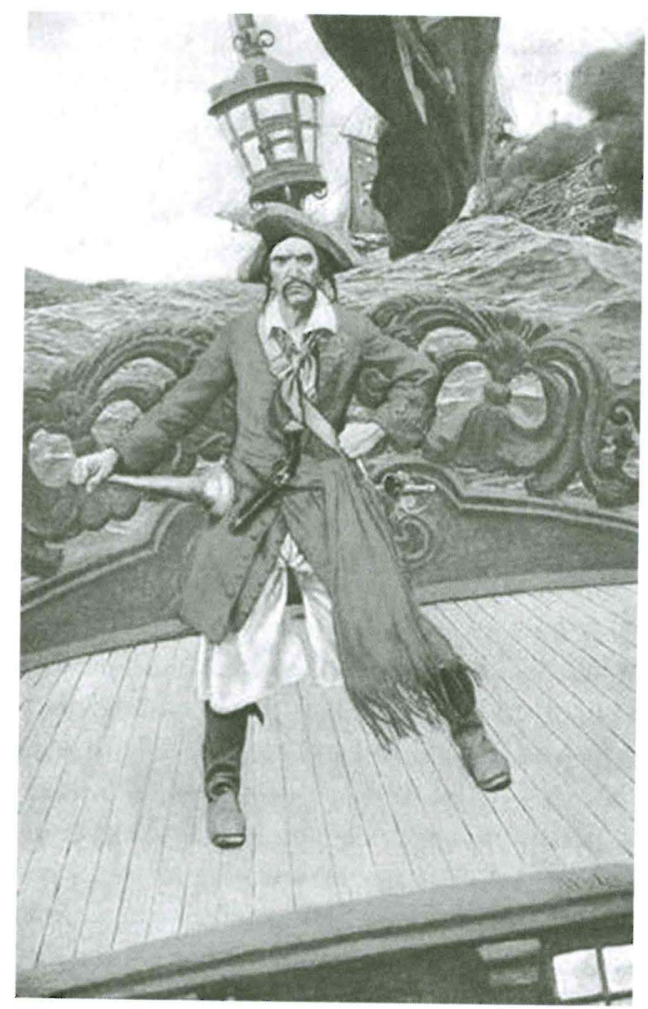

Figure 14.1 Howard Pyle, 'Captain Keitt', Harper's Monthly, August 1907

Pyle's contribution to the iconography of the pirate cannot be overestimated and goes back to his first contribution to Scribner's in 1877, appearing three years before Gilbert and Sullivan's Pirates of Penzance. ${ }^{1}$ In the preface to his Book of Pirates, Pyle outlined the perennial attractiveness of the pirate figure:

Courage and daring, no matter how mad and ungodly, have always a redundancy of vim and life to recommend them to the nether man that lies within us, and no doubt his desperate courage, his battle against the tremendous odds of all the civilized world of law and order, have had much to do in making a popular hero of our friend of the black flag. (xiv)

In the 1890s, Pyle also published illustrated editions of Defoe's Robinson Crusoe and Stevenson's Treasure Island for Scribner's Illustrated Classics and of Charles Johnson's 1724 General History of the Robberies and Murders of the

1 Pyle's first significant depiction of pirates was 'The Buccaneers and Marooners of the Spanish Main', in Harper's Magazine in 1887. 
Most Notorious Pyrates. $^{2}$ He thus allied himself to both an eighteenth-century tradition of representation and, more closely, to Stevenson's novel, itself regarded as 'the apotheosis of the 'penny dreadful' (Darton 295).

Pyle's comments about the liminal position of the pirate as a popular hero/ villain reflect contemporary perceptions of piracy and the pirate. For example, Samuel Walkey's protagonist in 'The King of the Seas' describes his reactions to La Valle, his pirate opponent: 'I could not help a great dash of admiration flooding my heart at his inimitable coolness - his perfect nonchalance' (180). Similarly, writing of Treasure Island in 1888, Henry James lauded Stevenson's Long John Silver as 'one of the most picturesque ... most genially presented villains in the whole literature of romance. He has a singularly distinct and expressive countenance, which, of course, turns out to be a grimacing mask. Never was a mask more knowingly, vividly painted' (qtd. in Carpenter 155). James's comments illustrate an ambiguity embedded in representations of pirates, deriving from their links to popular magazines and juvenile literature in particular. Moreover, James's references to the 'picturesque', 'the expressive countenance' and the 'grimacing mask' connect descriptions of villainy to its performance, to the essential theatricality of the piratical persona and, obliquely, to the direct influence of theatre conventions and practices.

Juvenile magazines appealed to the same clientele who regularly purchased the scenes and characters that were used in juvenile theatres. The magazines modelled their stories on the earlier adventure novels of Frederick Marryat, W. H. Kingston and R. M. Ballantyne. They also shared many of the same values: 'to entertain and instruct, to inculcate approved value systems, to spread useful knowledge, to provide acceptable role models' (J. Richards 3 ). The juvenile or toy theatres enabled children to share the experience of an exciting melodrama at home and to recreate for themselves the performances of popular actors and their theatrical contexts. In an article about juvenile theatre, Frank Jay describes the close connection between juvenile theatres and the emerging industry in the 1860s of juvenile fiction. $\mathrm{He}$ points to the fact that Edwin J. Brett, a founder of the long-running magazine Boys of England, launched the publication in November 1866 with a serial Alone in the Pirates' Lair, together with a toy theatre version - 'a complete new Play' - of the same name, 'consisting of eight scenes, seven sheets of characters, six wings, and foot-pieces, and a large stage front' (qtd. in Jay). ${ }^{3}$

This commercial crossover suggests the absorption of an older tradition to launch a new venture for a new market. The industry of toy theatres actually coincides with the heyday of melodrama. Skelt began his business in the early 1840s, while William West inaugurated the fashion for publishing juvenile plays in 1811 and continued his business until 1832. West went to great lengths to engrave representations of famous actors like Edmund Kean and T. P. Cooke and selected plays that represented the

2 In his collection The Buccaneers and Marooners of America (London: Fisher Unwin, 1891).

3 From Boys of England, 27 November 1866: 16. 
current melodramatic taste, including Black Ey'd Susan and The Red Rover. ${ }^{4}$ In his Memories and Portraits, Stevenson devotes a whole chapter to juvenile theatres and remembers with effervescent pleasure the acquisition of sets of Skelt's Juvenile Drama in Edinburgh, referring directly to the plays he had possessed as a child, including The Red Rover, My Poll and My Partner Joe, The Smuggler and Der Freischutz. ${ }^{5}$ These 'penny plain and twopence coloured' (198) were to influence his later work profoundly: 'Out of this cut-and-dry, dull, swaggering, obtrusive, and infantile art, I seem to have earned the very spirit of my life's enjoyment; met there the shadows of the characters I was to read about and love in a late future' (209).

The Red Rover undoubtedly helped shape elements of Treasure Island and it is therefore worth pausing to consider why this play was so enduring and influential. The Red Rover, a version of J. Fenimore Cooper's novel by Edward Fitzball, was staged at London's Adelphi theatre on 9 February 1829. Cooper's novel had been published in London and Paris in 1827 and adapted for the stage as early as 1828 in the United States. ${ }^{6}$ Cooper had made it clear that his portrayal of the Red Rover was intended 'to show the manner in which men of the fairest promise can be led astray by their wayward passions, and to prove how narrow the boundaries become between virtue and vice' (427). These ambiguous attributes would appeal to any actor-manager. Fitzball himself was one of the most successful melodramatists of the first half of the nineteenth century. He adapted Cooper's The Pilot for the Adelphi in 1825 and wrote The Flying Dutchman: or, the Phantom Ship for the same theatre in 1827. Both of these came under the management of Frederick Yates, a charismatic and versatile actor who played the title role of the Red Rover [Figure 14.2]. The Times thought he played the role 'with great spirit' ('Adelphi Theatre' 3); and Henry Crabbe Robinson, who had seen the production on 17 March 1829, found that he 'looked the bold pirate to perfection and his powers of mimicry made him an excellent performer of characters in disguise' (127). The Stage or Theatrical Inquisitor felt that the staging elements would ensure the production's success: 'The story is much altered from the novel ... but there is sufficient life, bustle, burning, blazing and dancing ... to make it a favourite for some time with the public' (The Stage or Theatrical Inquisitor, February 1829, 102). By September 7 it was being produced at the Surrey theatre (the old Royal Circus) with T. P. Cooke given top billing as the resourceful sailor, Fid, and the Rover played by the theatre's manager, David Osbaldiston. ${ }^{7}$

4 See Ralph Thomas, 'Juvenile Drama', Notes and Queries, 18 October 1873, quoted by Jay.

5 Originally published as an article in The Magazine of Art, April 1884.

6 In a version by Samuel Chapman at the Chestnut theatre, Philadelphia, 28 February 1828. The version was staged at the Lafayette theatre, New York on 26 May 1828 and continued to be performed as late as 1879. (See James Rees's Old Drury of Philadelphia: A History of the Philadelphia Stage, 1800-1835 (Philadelphia: U of Philadelpha P, 1932), 138.)

7 On the continuing popularity of versions of the play see John D. Gordan, 'The Red Rover Takes the Boards', American Literature 10.1 (March 1938): 66-75 and George Speaight's Juvenile (London: Macdonald, 1946). 


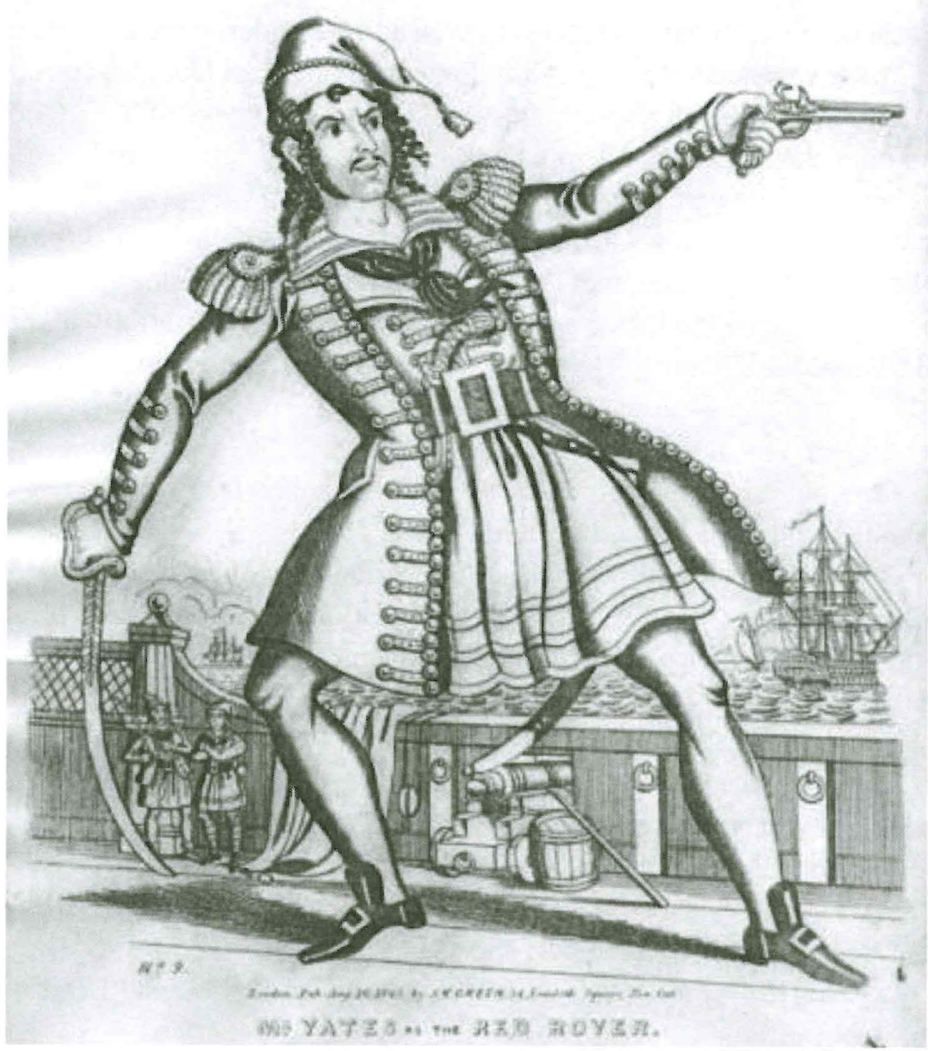

Figure 14.2 J. K. Green, 'Characters and Scenes in The Red Rover' (1842)

The play was billed as a 'nautical burletta' at the Adelphi; at the Surrey it was simply announced as a 'nautical drama'. The Adelphi, situated on the Strand in the heartland of London's West End, was closer to the two patent theatres, Covent Garden and Drury Lane. They were the only theatres licensed to perform the 'legitimate' drama. As an 'illegitimate' theatre, the Adelphi risked being prosecuted for performing plays that contained dialogue. Yates was sufficiently diplomatic to use the old, and increasingly irrelevant category of 'burletta' to describe The Red Rover, despite the fact that by 1829 the distinctions between 'legitimate' and 'illegitimate' plays were blurred and often ignored. ${ }^{8}$ South of the Thames and outside the City of Westminster, the Surrey, since its days as the Royal Circus, had been rebuilt to cater

8 The burletta was defined as 'a drama in rhyme which is entirely musical; a short piece of recitation and singing, wholly accompanied more or less by an orchestra', George Colman, Random Records, 1830, 146 quoted in George Rowell, The Victorian Theatre (Cambridge: Cambridge UP, 1978), 10. 
for the large numbers of local residents as well as for a wider, more affluent audience. The Red Rover was added to a programme which contained Douglas Jerrold's longrunning Black Ey'd Susan and emphasized the attractiveness of T. P. Cooke, who played in both. Just as at the Adelphi the play had been a vehicle for Yates, so at the Surrey it became a vehicle for a star performer of British sailors.

As contemporary reviews indicate, the performance of the stage pirate reflected the public's appetite for spectacular theatrical display. Audiences also responded to the performance of the pirate's persona - the mask referred to by Henry James - which allowed the actor to demonstrate a capacity for deception, disguise and illusion. The list of costumes for The Red Rover production included disguise elements like flaxen and grey wigs that allowed the Rover to conceal his real identity. For the Pirate, the costume is 'a blue jacket trimmed with gold lace, red stocking tights, red waistcoat, white petticoat, trowsers [sic], blue cloth cap hanging down at the side, black belt, mantle shoes and buckles' (The Red Rover, Dicks' Standard Plays, No. 450, nd, I.viii). The illustration [Figure 14.3] captures the moment of revelation as the Rover discards his cloak and flourishes the red flag that identifies him to Fid and to the hero, Lieutenant Wilder:

ROV: You start: are there no king's ships but those of England? No flags but those of George? What think you of the lily of France? (takes up a white flag, waves it and drops it.) Or the gorgeous Spaniard? (Unfurls another flag as before.) or the Portuguese? (Displays a third flag.) You see I boast the colours of all nations.

WIL: And which of the colours do you yourself assume?

ROV: This. (Waving a crimson flag and throwing off his mantle) Behold and know me! (Music)

WIL: The Red Rover?

ROV: Ay, the Red Rover! (Music. Strikes a gong which is hanging near R. 3rd. E. And the deck is filled with whole crew, all armed) (I.viii)

The script emphasizes the deceptive nature of the pirate, able to hide behind the colours of a flag. Moreover, the staging of the Rover revealing himself by unfurling, waving and dropping four separate flags is both flamboyant and dramatic. The illustration, which depicts the scene where the Rover reveals himself as a pirate, has been adjusted to include many more crew on stage, further emphasizing the scene's theatricality. It also adjusts the persona of the pirate to reflect a young, slightly androgynous young man, not the 32-year-old of Yates's theatrical portrait, in order to tap into contemporary expectations and images of the pirate.

At the same time, however, the theatrical performance fleshes out Cooper's original plans for his characters. When Madame de Lacy, who, together with her daughter, has been abducted by the pirate, pleads for their lives when confronted by a mutinous crew intent on their deaths, the Rover responds: 'Lady, this is bold language to sound in the ears of a blood-seeking, remorseless pirate, since 'tis plain you believe me such; but know, that vengeance is at hand - such vengeance as the hunted and denounced freebooter best likes, and is proud to inflict-mercy'(II.xiv). 


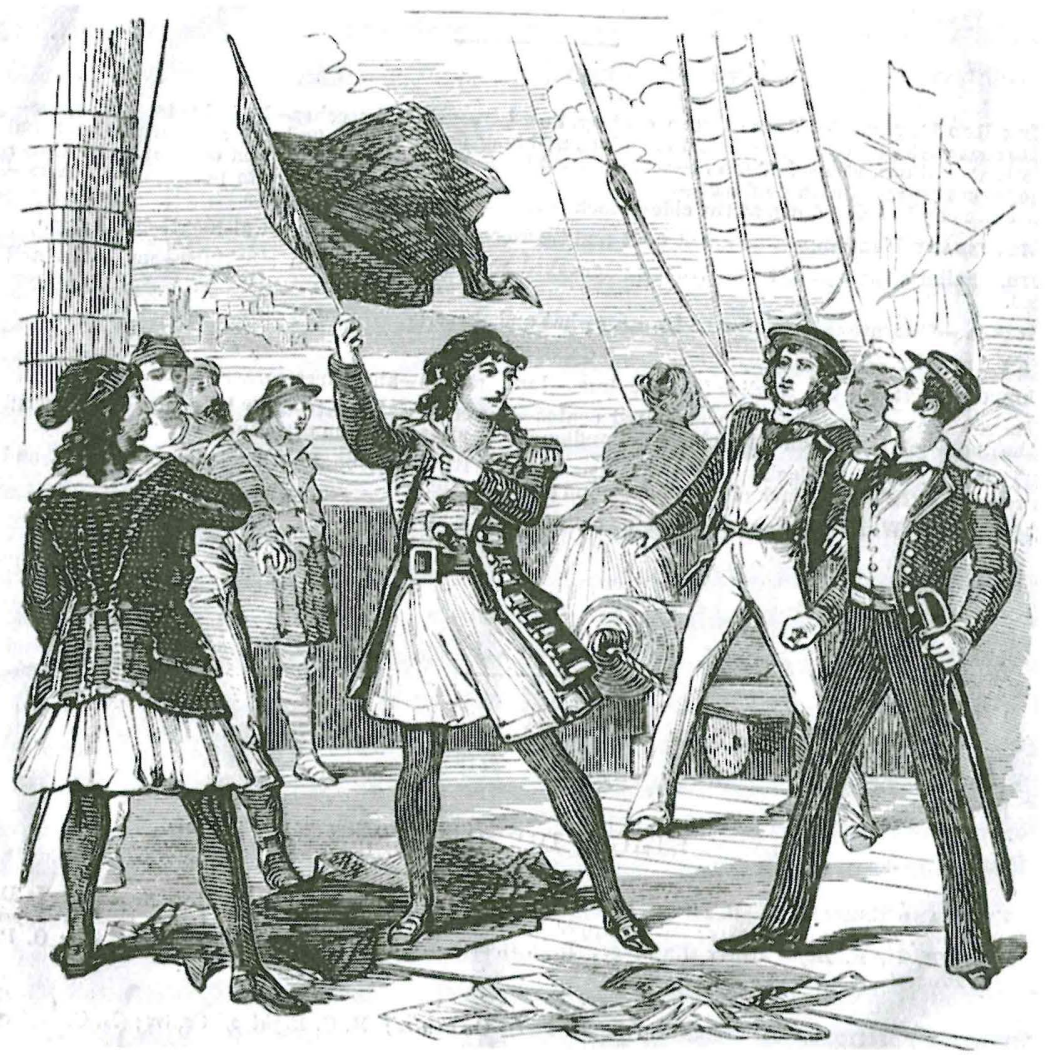

Figure 14.3 Edward Fitzball, The Red Rover, frontispiece to Dicks' Standard Plays, No. 450 (undated, possibly 1843)

The disparity between the Rover's outward show and inner sensitivity, public reputation and private nobility, emphasizes the complexity of Cooper's character. The play ends as the chief mutineer, Sam Cutreef, shoots the Rover, and the comic tailor Hector Homespun, sets the ship on fire:

ROV (laughing hysterically): Ha, ha, ha! So best: his ship shall be the Rover's funeral pile. (The flames issue from the hatchway-Re-enter the crew from both cabins. - The ship is seen burning - she begins to sink with the Crew-some fallsome ascend the rigging, others struggling as the ocean overwhelms them-Mast, rigging and Crew, all sink with the vessel.-The Red Rover is seen combating the waves, and at last meets his fate. - The Dart is seen at the back, with Lieutenant Wilder, Madame de Lacy, and Gertrude aboard, and Fid clinging outside the vessel, as the curtain descends.) 
The script contains no references to the novel's original eighteenth-century setting and any references to the Rover's involvement in the slave trade are suppressed. Nor is the play influenced by elements of the Romantic 'man of loneliness and mystery/scarce seen to smile, and seldom heard to sigh' (Byron, Corsair I.173-4). The contemporary relevance of the production would have received an additional boost from the report in The Times on the day of its opening at the Adelphi that 40 pirates captured off the coast of Africa were undergoing their final examination in court ('The Forty Pirates' 3). More significantly, in terms of the crossover between the traditions of representation, the portrait of Yates, combining a reasonably accurate portrait of the actor with a highly conventionalized melodramatic posture of aggression and defiance, is drawn from J. K. Green's Juvenile Drama published in $1842 .{ }^{9}$ Green himself was influenced by earlier representations of pirates, including those of J. C. Cross.

In 1851 Green published a halfpenny set of Blackbeard the Pirate; or the Jolly Buccaneers, originally published by West in 1824. Both owe their origins to J. C. Cross's Blackbeard; or, the Captive Princess, first performed on 9 April 1798, but not published until 1809. Jane Moody has argued for the significance of Cross's contribution to the evolution of melodrama and that the publication of his plays in 1809 'indicates the emergence of the minor play as a text to be read and imagined in the closet, not simply enjoyed as a theatrical spectacle' (30). The plays would provide a fertile resource for the juvenile drama and encourage other publishers like Cumberland, Duncombe and Lacy to issue collections of minor plays for performance.

Cross would have read one of the many editions of Captain Charles Johnson's A General History of the Robberies and Murders of the Most Notorious Pyrates, as well as Charles Johnson's (not the same man) The Successful Pyrate, first performed at Drury Lane in 1712 and published in 1713. From The General History he would have obtained the appearance of Blackbeard:

Captain Teach assumed the cognomen of Black-beard, from that large quantity of hair, which, like a frightful meteor, covered his whole face ... The beard was black, which he suffered to grow of an extravagant length; as to breadth, it came up to his eyes, he was accustomed to twist it with ribbons, in small tails, ... and turn them about his ears: in time of action, he wore a sling over his shoulders, with three brace of pistols, hanging in holsters like bandoliers, and stuck lighted matches under his hat, which appearing on each side of his face, his eyes naturally looked fierce and wild, made him altogether such a figure, that imagination cannot form an idea of a fury, from Hell, to look more frightful. (Johnson, 84-5)

From Johnson's play, he acquired a plot that used the exploits of another actual pirate, Henry Avery (also known as 'Every' or 'Avary', but possessing a number of other aliases). Avery was notorious for seizing the magnificent and heavily armed

9 By the end of 1829 at least two publishers of juvenile drama, William West and I. J. Dyer, had already brought the play out (Speaight 216-17). 
vessel, the Ganj-i-Sawai from the Emperor Aurangzeb in 1694 and legend has it that he also captured the Grand Mughal's daughter. Cross blended these two elements in what was advertised as 'a new grand spectacle, consisting of music, dance and action' at the Royal Circus. Blackbeard was to be played by Mr Crossman, who would appear in a 'grand equestrian entree' ('Jones's Royal Circus' 1) immediately before. Cross was carefully keeping within the terms of the Licensing Act of 1737 , which prohibited the use of spoken dialogue in theatres other than the patent ones. ${ }^{10}$ There are no descriptions of Blackbeard in the play itself. Perhaps spectators already knew the persona from engravings, or the character was regarded as merely a plot device whose actions determined his role. Certainly Cross pays little attention to historical facts or to geographical consistency. Avery's exploits took place near Madagascar, while Blackbeard's occurred along the North American coast and in the West Indies. The play is presented as a spectacular display of the various facets of villainy. Blackbeard (Figure 14.4) ${ }^{11}$ is a villain prepared to murder his wife, Orra, when she resents his obvious attraction to the captured princess Ismene, as well as a fellow sailor who refuses to shoot the young hero, Abdallah. At the end of the play, Blackbeard is wounded by the hero (not by the historically accurate Lieutenant Maynard who subsequently decapitated him in 1718) and falls overboard.

Despite its historical inaccuracies, the melodramatic forms and techniques of the staging reflected prevailing interests in the recreation of naval engagements, Eastern exoticism and even Gothic spectral visitations. The play opens with a song in which the pirates extol the virtues of grog and the jollity of a pirate's life, a necessary device included in most subsequent nautical melodramas. Blackbeard joins in and demonstrates his prowess by shooting out a candle with his pistol. The crew also contains a prototypical British sailor, William, along with his girlfriend Nancy, disguised as a member of the crew. The setting of cabins and decks, a staple of nautical drama, is complemented by locations in both Madagascar and the West Indies:

[he] extinguishes the lights; she becomes much agitated; he approaches her, drags her to the sopha [sic], solicits, threatens, etc. When a groan is heard, and THE APPARITION OF ORRA rises! Stalks across the stage, and vanishes.

- Blackbeard, with his sword drawn, apparently defying it-Ismene is horror struck. $(\mathrm{x}, 41)^{12}$

10 The Royal Circus had been built as a speculative venture in 1782 to cater to the rapidly expanding population of south London and to challenge Astley's Amphitheatre for spectacular displays of horsemanship.

11 The illustration, as that of Yates, is like a studio portrait of a performer frozen in a characteristic moment. Some attention has been paid, however, to the costuming which figures the skull and crossbones and Blackbeard's distinctive beard. Though the actor depicted is A. V. Campbell, the manager of Sadler's Wells theatre 1825-32, it can represent the original since no illustrations of Crossman survive.

12 This reference is to the scene and page number. 


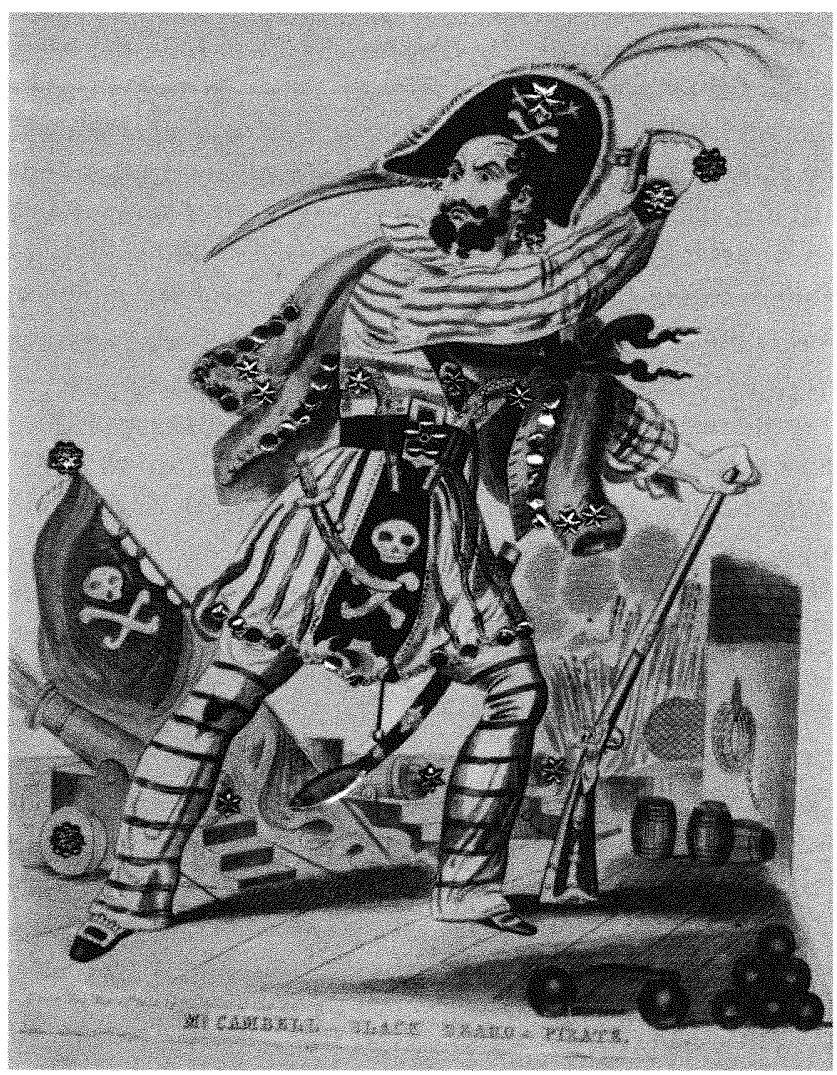

Figure 14.4 A. V. Campbell, 'Mr. Campbell as Blackbeard the Pirate'

Blackbeard is clearly portrayed as a villain, ruthless and totally unsentimental in his attitudes towards women and his crew, a far cry from the Red Rover and his innate sense of decency.

Though naval dramas would continue to find a place on the popular stage - especially among the huge Drury Lane autumn melodramas - until the end of the nineteenth century, by mid-century the memory of British naval exploits had dimmed. The pirate's lair and the high seas had been replaced by the drawing room and the streets as the primary locations for exploration of 'wayward passions' and the 'narrow boundaries between virtue and vice'. Certainly, as we have seen, the pirate continued to thrive in the pages of boys' magazines and the cut-outs of the juvenile drama, where the figure's menace and ruthlessness found a place. On stage the performance of those qualities was mitigated by a growing middleclass self-consciousness about the simplistic values of melodrama and their oldfashioned modes of expression. Nevertheless, even if audiences were becoming less tolerant of 'the grimacing mask' of the performer and more inclined to favour 
restraint and understatement, their fondness for burlesque and pantomime gave the pirate figure a lasting place on the popular stage. Within these two genres the ambiguities of the pirate could be explored and given a fresh meaning.

The complexities of the stage pirate are typically expressed in H. J. Byron's Robinson Crusoe; or Harlequin Friday and the King of the Caribee Islands!, performed at the Princess's theatre on 26 December 1860. The work, labelled 'a Grotesque Pantomime Opening', contains three pirates: Cutpurse, Gougeye and their captain, Will Atkins. The names of the first two signal their direct descent from Cutreef in The Red Rover. The other name is a deliberate fusion of William, a name long identified with the sailor from Blackbeard to Black Ey'd Susan, and a surname associated with the unromantic ordinariness of tradesmen and servants. It was an unlikely name for a figure described as a 'freebooter, smuggler, pirate, buccaneer and blackguard'. This ironic juxtaposition was further enhanced for the audience by the fact that the role was played by J. G. Shore who, by 1858 , was identified with jeune premier roles. ${ }^{13}$ Moreover, by 1860 the Princess's theatre had established a stellar reputation. Charles Kean had developed it as a venue for elaborately staged Shakespeare and the 'gentlemanly melodrama' of Dion Boucicault in the $1850 \mathrm{~s}$, and it had become a bastion of middle-class respectability. For pirates to appear at the Princess's theatre, then, is seemingly at odds with the theatre's apparent aims, or perhaps a reffection of the wholesale assimilation of the pirate into nineteenth-century cultural life.

H. J. Byron was particularly noted for his burlesques of melodrama and his verbal pyrotechnics, and this is reflected in his production of Robinson Crusoe. When Atkins enters in Scene 1, the stage directions describe him as 'a buccaneer of the true Cobourg stamp, enveloped in a rough pea jacket, and covered with every variety of offensive weapon' $(i, 254) .{ }^{14} \mathrm{He}$ also has 'a piece of black plaister [sic] which extends the entire length of his countenance'. However, as he kneels at the feet of the heroine, Pretty Jenny Pigtail, he exclaims:

You are my government; by persecution

You have induced in me a revolution.

I used to smoke and drink and use bad language;

But now my bosom is a prey to anguiage. $(i, 255)$

His followers also demonstrate an incompetence that belies their appearance. When Jenny tries to run away, they run after her 'and missing her come whack

13 J. G. Shore had worked at the Adelphi theatre and would join Marie Wilton and $\mathrm{H}$. J. Byron when they took over the management of the Prince of Wales's theatre in 1864. See C. E. Pascoe, The Dramatic List (London: David Bogue, 1880) sv. J. G. Shore.

14 All references to the play include scene and page number and are drawn from Michael Booth's recension of the text in English Plays of the Nineteenth Century, volume 5 (Oxford: Oxford UP, 1975). See also Lacy's edition, volume 49, nd. http://victorian.worc. ac.uk. 
against each other; this is repeated, and they come with a thump against Atkins, who strikes them and seizes Jenny' (i, 256). She struggles ineffectually, but when the hero, Robinson Crusoe, enters: 'He knocks down the two Ruffians with back-handed blows, and floors Atkins with a driver; then stands C. With Jenny insensible in his arms. Picture' (i, 257). All three pirates then run off, cowardly and powerless. The Indians who appear on a desert island in Scene 3 'brandishing their tomahawks fiercely' (iii, 264) are rendered just as ineffectual by their predilection for rum. After Jenny is abducted by Atkins, she appears on stage 'with her hair down ... and the wild, determined manner of melodramatic heroines in the Third Act' $(v, 270)$. She seizes a large pistol from Atkins and 'stands at bay':

Come on at once! [Wildly] Ha, ha, ha, ha!

To which Atkins replies:

Miss P., you're not at the Victori-a.

Though the lorn damsels there you thus burlesque, you

Will find no gallant tar comes to the rescue. $(v, 270)$

Atkins collapses in fright when he sees the Indians. At the end of Scene 7, Crusoe and Atkins confront each other. Atkins and Crusoe run on stage 'à la Macbeth' and 'à la Macduff' respectively, while Atkins is attacked by Crusoe's Goat and Parrot. The first part of the pantomime concludes with:

a terrific combat, the Goat and Parrot acting as seconds. At last Crusoe misses his foot and falls ... Atkins is about to despatch Crusoe when Jenny rushes out and wards off the blow; at the same time the Dog flies on, and fastening on to the neck of Atkins as in canine dramas, drags him to the ground. They rise, swing around, roll over, down to the footlights and back again, etc. (vii, 277)

The action is interrupted by the figure of Liberty, who transforms the scene into the Golden Grotto of Christmas and the main characters into Harlequin, Columbine and Pantaloon in preparation for the comic scenes of the harlequinade, the traditional pantomime ending.

The ambiguities of the pirate figure are now played out on stage as a clash between modes of representation. Reference to an acting style appropriate to the Victoria theatre (and its older identity as the Coburg) prompts the audience to recognize an outmoded performance style that made it laughable and to congratulate themselves on their sophisticated appreciation of irony. W. S. Gilbert would capitalize on this affectionate parody of the outdated (and, by inference, working-class) theatrical conventions in a conservative middle-class forum later in the century.

Gilbert had long been associated with burlesques and to a lesser extent pantomime. In fact, by 1870 he was identified as a 'leviathan of burlesque' (qtd. in Stedman, W. S. 
Gilbert 62). ${ }^{15}$ Before he wrote The Pirates of Penzance, he had already penned Our Island Home, an 1870 play featuring pirates. The conceit of having Frederic as an indentured pirate apprentice is taken from that play, as is the statement in the earlier play by the melodramatic pirate chief, Captain Bang, that as a child he had been taken by his nurse to the seafront to be apprenticed to a pilot (Stedman, Six Comic Plays 140). Yet Gilbert hadn't originally conceived of the play as being about pirates. Ian Bradley states that the provisional title of the play, The Robbers, points to a story that had been originally conceived as a tale of burglars and policemen, and the shift to piracy only took place while Gilbert was in the United States (86). The entry of the pirates in Act 2 of Pirates of Penzance, clutching burglars' tools, preserves some of the spirit of the original play, although it renders the pirates somewhat ambiguous.

Critical reviews did not always emphasize the importance of the pirates to the plot. After the performance required to preserve the play's copyright at Paignton's Bijou theatre on 30 December 1879, The Pirates of Penzance opened in New York at the Fifth Avenue theatre the following night. The review in the New York Times makes no reference to the pirates and focuses on the humour of the absurd situation and the abilities of the performers. When it opened in London at the Opera Comique on 3 April 1880, however, references to the comic opera's antecedents were clearly noted: ${ }^{16}$ 'The plot is well described as a satirical burlesque upon the conventional romance of buccaneering, and the sentimentalities of the pirates' career on the stage and in fiction' (Musical Times 444). ${ }^{17}$

The nexus between the stage representations and those in juvenile fiction was further emphasized by the Stage Directory (1 May 1880) that compared the humour of the play to that of a 'children's story-book'. The representation of the pirates 'dressed picturesquely after the Red Rover style, with red caps, short jackets, and skirts reaching to the knee' (Dramatic Notes 20) preserved the tradition of the earlier play in its toy theatre manifestations, and its relevance to children received a fresh impetus when D'Oyly Carte rehearsed H.M.S. Pinafore and The Pirates of Penzance with juvenile companies aged between 10 and 13 as Christmas specials (Beatty-Kingston, 80-82).

The opening of the play preserves a connection with Blackbeard in that both begin with a rousing chorus that glorifies the pirate life. However, the attitude of the Pirate King toward his crew differs from the earlier play. He is not the ferocious, dominating figure of a Blackbeard. Indeed, in the licensing copy of the play the Pirate King plays a menial role, not preserved in the final staged version, that erodes his role as a leader:

But to cook your meals I don't refuse

And I black piratical boots and shoes

15 See The Graphic, 18 April 1870.

16 The Opera Comique had opened in 1870 in the West End as a home for comic opera, French comedy and musical extravaganzas. D'Oyly Carte became its manager in 1874 and had been responsible for The Sorcerer (1877) and H.M.S. Pinafore (1878).

17 Quoting the review in the Paignton and Newton Directory, 31 December 1879 of the copyright performance. 
I clean your knives, I bake your bread

I light your fires - I make your beds ... (Paignton version, Gilbert 196)

The pirates themselves have all the trappings of ferocity, but, as Abigail Burnham Bloom notes in her discussion of 'duty', their opera-bouffe context completely undermines their marauding intentions. A reviewer for The Graphic notes that:

the pirates themselves and their mock-ferocious Captain, are a strange lot ... The strong sense of 'duty' entertained by these pirates, their tender sympathy for orphans, and 'with all their faults' their loyal attachment to the Queen and reverence for 'our House of Lords', are unique in the history of sea marauders. (371).

The illustration [Figure 14.5] of the 'paradox scene' in Act 2 preserves the characteristic pose of earlier pirate representations but is undercut by the absurd parallelism of Ruth the pirate maid's stance and the imperturbability of Frederick in the face of their threats. The setting of a ruined chapel recalls the context of Gothic melodrama and its connection with Romantic antecedents. ${ }^{18}$ The 'pirates' of Penzance are, of course, ultimately revealed to be men of noble birth, which explains their inadequacies as swashbucklers and their inability to terrify. Far more appropriate in his villainy and capacity to fill audiences with dread was Captain Hook of J.M. Barrie's Peter Pan who, along with Long John Silver, has to be one of the quintessential pirate rogues of the long nineteenth century.

Captain Hook's development as a pirate was not, however, entirely straightforward and the dramatization of piracy in Peter Pan was as complicated and ambiguous as it had been for a number of Hook's predecessors. Writing in 1934, the year of her father Gerald's death, Daphne du Maurier evoked his performance as Captain Hook in Peter Pan, which had opened at the Duke of York's theatre on 27 December 1904. From her description, it would appear that the performer had retreated from Gilbert's absurd faux pirates and restored the dark violence that had been present in Cross's Blackbeard:

When Hook first paced his quarter deck in the year 1904, children were carried screaming from the stalls, and even big boys of twelve were known to reach for their mother's hand in the friendly shelter of the boxes. How he was hated, with his flourish, his poses, his dreaded diabolical smile! That ashen face, those bloodred lips, the long, dank, greasy curls; the sardonic laugh, the maniacal scream, the appalling courtesy of his gestures; and that above all most terrible of moments when he descended the stairs and with slow, most merciless cunning poured the poison into Peter's glass ... Gerald was Hook; he was no dummy dressed from Simmons'

18 The drawing of the Pirate King is a reasonably accurate depiction of Richard Temple, who created the role and had a long association with the D'Oyly Carte Company. He would go on to play the Mikado (1885) and in revivals of The Pirates of Penzance thereafter. 


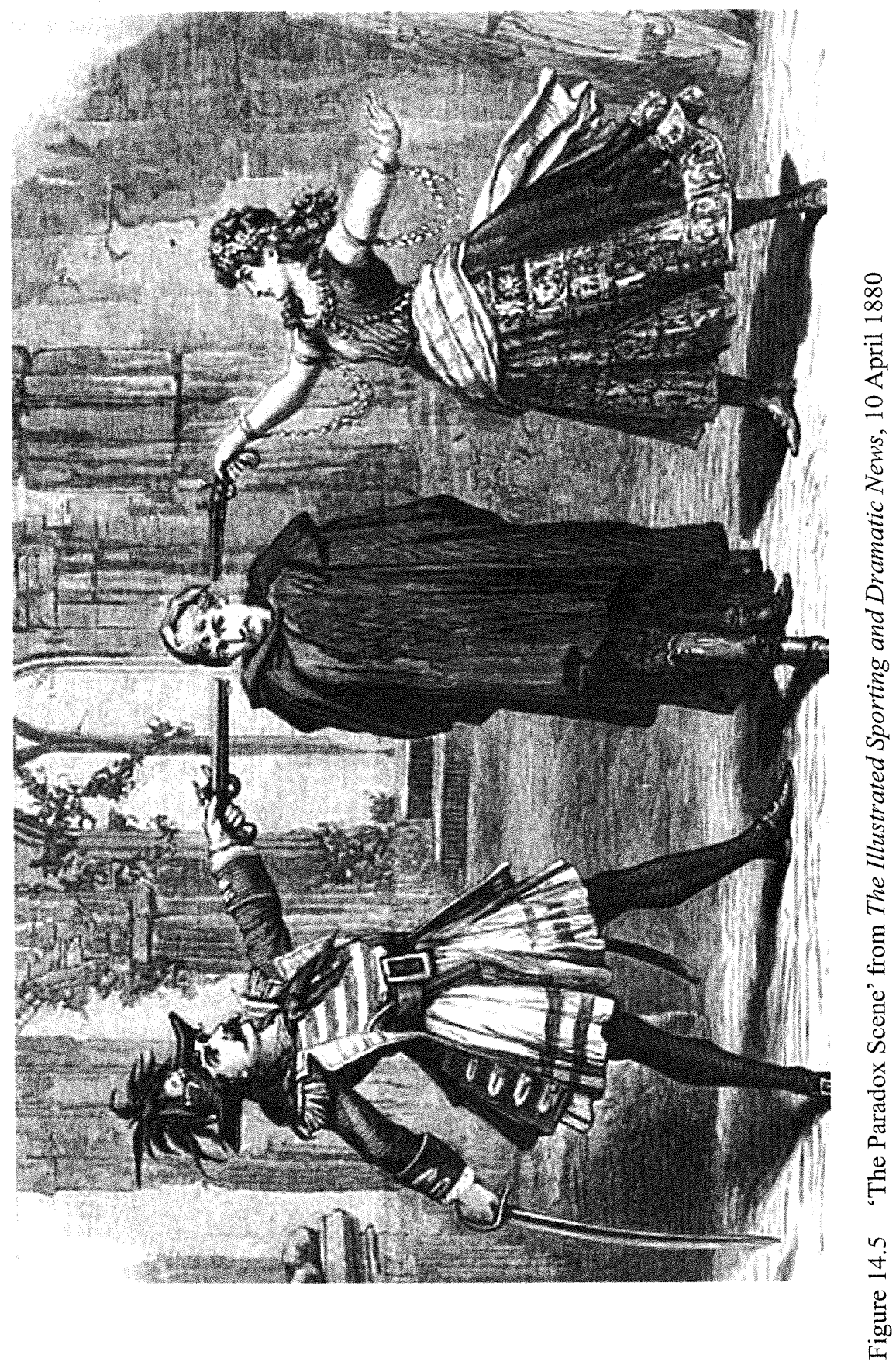


in a Clarkson wig, ranting and roaring about the stage, a grotesque figure whom the modern child finds a little comic. He was a tragic and rather ghastly creation who knew no peace, and whose soul was in torment; a dark shadow; a sinister dream ... He was the spirit of Stevenson and of Dumas, and he was Father-but-for-the-graceof-God; a lonely spirit that was terror and inspiration in one. (110-11)

Thus, Gerald du Maurier appeared to have captured an authentic pirate, closer to Howard Pyle's illustrations than to a staged replica or a composite of inherited theatrical conventions. Nevertheless, the description is undoubtedly coloured by his daughter's fascination with Gothic romanticism and her own complex obsession with him as a man. The account may, therefore, owe as much to Daphne du Maurier's fascination with Byron's Corsair and memories of performances of The Flying Dutchman as to her recollections of the actual production of Peter Pan. Indeed, since she was only three years old at the time of the production, it is questionable that she would have remembered so much of it. She probably witnessed one of the revivals in which her father reprised the role and she would have been familiar with the text of the play which Barrie had resisted publishing until 1928.

The evolution of the pirates in Peter Pan was a complex one. Much has been written about Barrie's obsession with the Llewelyn Davies family and its effect on his writings about children, ${ }^{19}$ but the portrayal of Captain Hook is also a product of Barrie's tastes in reading and theatregoing. He had certainly read Treasure Island and Ballantyne's Coral Island (Green 407), as well as Charles Johnson's 1724 history; he had seen The Pirates of Penzance and he was determined that his pirates would not be Gilbert and Sullivan travesties, a point he made to the designer William Nicholson. Yet even at the outset his intentions were compromised. Du Maurier refused to wear 'a wig of purple chenille, arranged to look like snakes' (Steen 98) for Hook, and on the first night he covered a complicated scene change by performing impersonations of Henry Irving in The Corsican Brothers, Beerbohm Tree as Svengali in Trilby and John Martin Harvey in The Only Way, Freeman Wills's adaptation of Dickens's $A$ Tale of Two Cities. Hardly surprisingly, Irving's grandson Laurence, who saw du Maurier as a child, remembered Hook played 'with touches of parody, that were echoes of the Lyceum' (Irving 87), the theatre where his grandfather had made his reputation. Based on du Maurier's performances, then, Hook was both a thrillingly piratical figure as well as a humorous one.

The published version of the play reveals further complications to the depiction of Hook. Barrie added material to the play after the publication of his novel version, Peter Pan and Wendy in 1911, and elaborated in the whimsical account of Hook's supposed career at Eton published in The Times in 1927. ${ }^{20}$ Hook's first appearance on stage in Act II is described in the stage directions:

19 See Andrew Birkin, J.M.Barrie and the Lost Boys (London: Constable, 1979).

20 'Captain Hook at Eton, a strange story' appeared in the 8 July 1927 number of The Times and was republished in the collection M'Conachie and J.M.B: Speeches (New York: Scribners' Sons, 1939). 
cadaverous and blackavized, his hair dressed in long curls which look like black candles about to melt, his eyes blue as the forget-me-not and of a profound insensibility, save when he claws, at which time a red spot appears in them. He has an iron hook instead of a right hand ... He is never more sinister than when he is most polite, and the elegance of his diction, the distinction of his demeanour, show him one of a different class from his crew ... This courtliness impresses even his own victims on the high seas, who wrote that he always says 'Sorry' when prodding them along the plank ... At his public school they said of him that he 'bled yellow'. In dress he apes the dandiacal associated with Charles II ... (II, 27-8) $)^{21}$

Later in Act IV as he is about to poison a sleeping Peter Pan, Barrie qualifies Hook's intentions: 'Does no feeling of compassion disturb his sombre breast? The man is not wholly evil: he has a Thesaurus in his cabin, and is no mean performer on the flute. What really warps him is a presentiment that he is about to fail' (IV, 60).

This portrait of a gloomy, meditative villain is captured in the illustration (Figure 14.6) as Hook contemplates his plans to make the captured Boys walk the plank:

The terrified Boys are prodded up and tossed about the deck.

Hook seems to have forgotten them; he is sitting by the barrel with his cards.

(V.i.65).

At the end of the play, Hook's plot to blow up the ship is thwarted and Peter Pan is revealed to be unscathed:

At this sight, the great heart of Hook breaks. That not wholly unheroic figure climbs the bulwarks murmuring 'Floreat Etona', and prostrates himself into the water, where the Crocodile is waiting for him open-mouthed. (V.i.65)

The remaining pirates retain the trapping of ferocity in their costuming, but they are no more effectual than the pirates of Byron's pantomime or Gilbert's operetta. They are despatched by the Boys in Act V, who prove more than a match for their cutlasses and pistols, and are sustained by their patriotism. They sing the national anthem when they are about to walk the plank and respond enthusiastically to Wendy's advice that their real mothers would 'hope [their] sons will die like English gentlemen' (V.i.66-7). Thus, the moral and educational values enshrined in Chums and Boys' Own Paper and the performance values of burlesque and pantomime are never far from the surface. ${ }^{22}$

21 References are to act and page number of the Samuel French edition of Barrie's Peter Pan.

22 The pantomime and burlesque pedigree was further reinforced by the production's indebtedness to the achievements of the Conquest family at the Surrey theatre, whose pantomimes in the 1890 s saw the demonstration of a flying apparatus that enabled mid- 


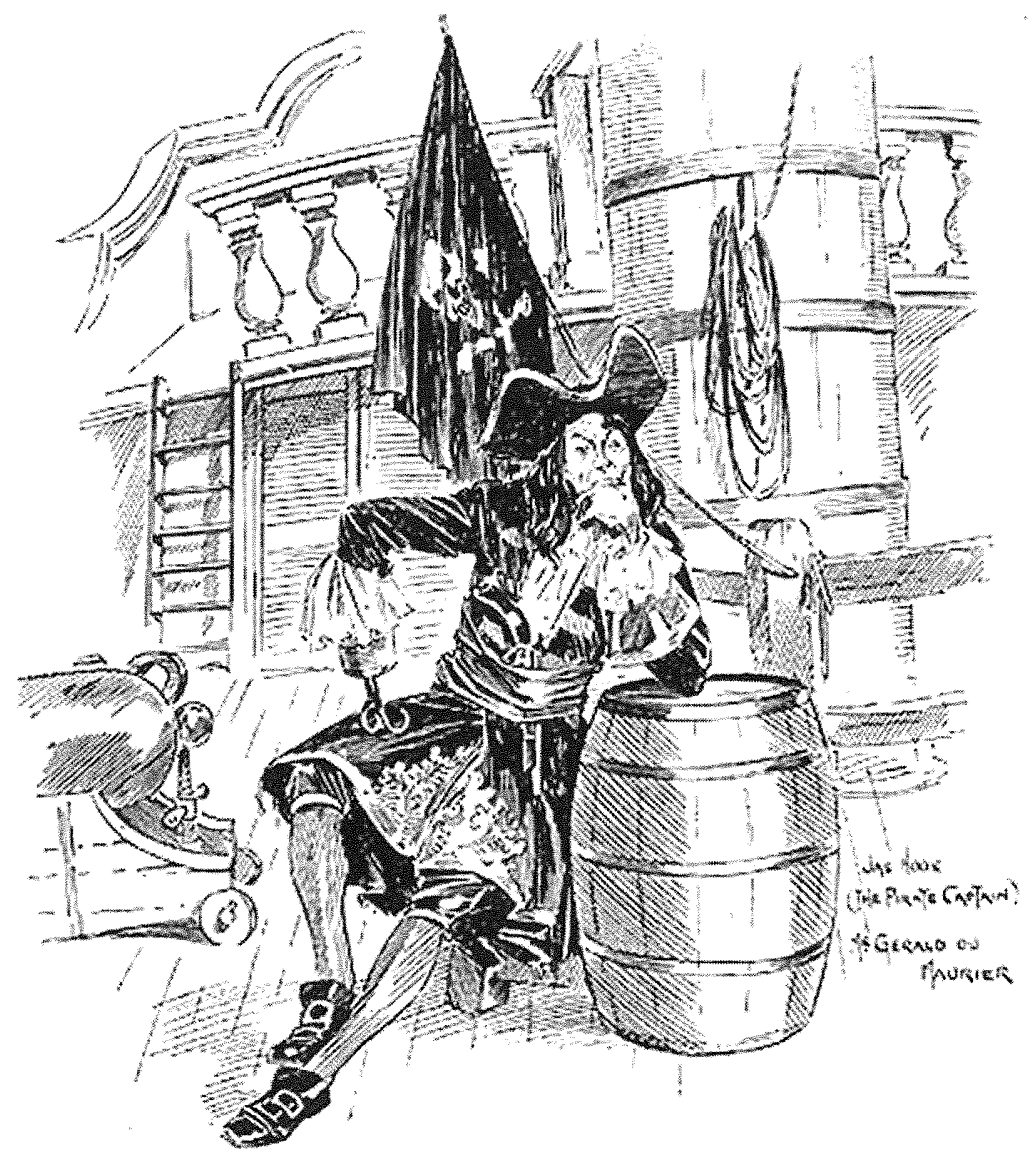

Figure 14.6 Gerald du Maurier as Captain Hook, The Sketch, 4 January 1905

When Hook exults at the prospect of making his captured boys walk the plank, his speech is punctuated by the sound of his confederate Smee tearing pieces of calico to make the pirates' clothes and stitching them together on a sewing machine. Smee, played by George Shelton, with his spectacles and description as a 'Nonconformist pirate', is a direct descendant of Homespun, the captured tailor in The Red Rover. Even Hook's speeches contain elements of parody, in particular, his outlandish oaths 'split my infinitives', 'uvula and tonsils' and 'By Gaius and Balbus'. All these touches restore an ambiguity that may not have been part of Barrie's original plans and contributed nothing to Daphne du Maurier's memory of her father's performance. Certainly the critics saw du Maurier's

air dances, underwater scenes and electrically enhanced fairies. See Frances Fleetwood, Conquest: The Story of a Theatre Family (London: Allen, 1953), 161-2. 
interpretation as a burlesque of piracy: The Times described his performance as 'luridly melodramatic' ('Duke of York's Theatre' 4); his use of 'expurgated oaths and melodramatic airs, is a splendid piece of burlesque' (qtd. in Agate 135). ${ }^{23}$ Even if du Maurier performed Hook as 'elegant and stylisé to the last degree' in 1904, the depiction of the pirates contained elements that ensured that their eccentric behaviour would become ultimately indistinguishable from parody: 'The pirates ... gradually became more and more Gilbert-and-Sullivan, and finally ended up as Sullivan-and-water' (Steen 98).

Perhaps Alfred Noyes writing in 1905 sums up best the traditions of pirate representation and the place of Peter Pan within that tradition:

What pirates these are ... that might have stepped straight out of the red and yellow illustrations of an old broad-sheet ballad; pirates of the imagination ... not earthly, but ideal pirates, who wear boat-cloaks and big boots and bloodspotted bandages round the head. Each of them is the delightful essence and consummation of a thousand conventions ... It is the last word on pirates. It is the story of pirates reduced to the simplest terms; stripped of unnecessary details and realities, and made eternal as boyhood. For 'grown-ups' it has an exquisite humour. It is like a delicious and subtle parody of all the pirate stories $\ldots$ and yet it is as real and vivid as 'Treasure Island.' ... I had a great choking thought during those wonderful twopenny-coloured episodes - if only Robert Louis could have been there to see them! (114).

It would appear, therefore, that by 1904 staging the pirate had reached a point where it could develop little further. The pirate in the nineteenth century had been a key figure in the complex discourse of conventions of performance and 'inward signification', of historical fact and 'figural truth' (Meisel 4) that informed the shared structures of nineteenth-century representational arts. It would now be left to the new medium of film to untangle the strands of representation and select for its own purposes the elements of juvenile adventurism or mocking irony that would best suit its purposes and a new market.

23 Unidentified review, 27 December 1904. 